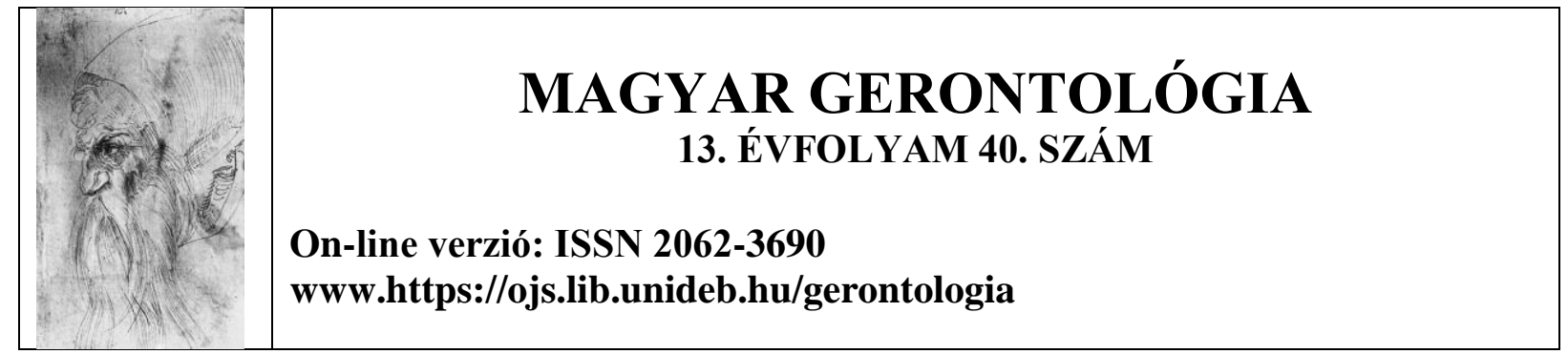

\title{
ÁLLATTARTÓ IDŐSEK EGÉSZSÉGI ÁLLAPOTA
}

\section{Virginás Zolna}

Debreceni Egyetem, Szociológia és Társadalompolitikai Doktori Iskola

Kulcsszavak: egészség, állatok, idősek, terápia.

\begin{abstract}
Absztrakt
Az ember egy komplex lény: biológiai, pszichikai és társadalmi tényezők ötvözete. Életünket jelentős mértékben befolyásolják az egész világra kiterjedő társadalmi hatások és kommunikációs hálózatok. Az egészséghez harmónia és összhang szükséges a természettel, önmagunkkal, embertársainkkal és a természetfelettivel. Az állattartás nem csupán egy életforma, hanem naponta ismétlődő társadalmi rítus, szimbolikus értékekkel, társas interakciókkal. Kutatásom célja állattartó, különböző szociokulturális környezetben élő idős emberek egészségi állapotának vizsgálata.
\end{abstract}

Keywords: health, animals, elderly, therapy

\begin{abstract}
The human is a complex being: a combination of biological, psychological and social factors. Our lives are significantly influenced by worldwide social influences and communication networks. Animal husbandry is not only a way of life, but a daily social rite, with symbolic values and social interactions. Health requires harmony with nature, ourselves, our fellow human beings and the supernatural. The aim of my research is to examine the health status of elderly people and their interactions with animals.
\end{abstract}




\section{Bevezetés}

Jelen és jövő társadalmunk egyik aktuális kihívása az idősek helyzete: elmagányosodásuk, kapcsolathálóiknak beszükülése. A fenntartható fejlődés és jövő biztosítása érdekében, az „ezüst gazdaság” diverzitásában fejleszteni kell a mentális egészséggel kapcsolatos szolgáltatások palettáját, figyelni kell a jólléti szolgáltatásokra. Tudjuk, hogy a társadalmi patológiás tényezők semlegesítése a társadalmi immunogén tényezők (vallás, társas támogatás, társas megbirkózás, barátság, lelki béke, család...), pszichoszociális puffer rendszerén keresztül lehetséges, melyek segítenek az egészségmegörzésben, az egyensúly fenntartásában, a betegségek megelőzésében és a hatékony gyógyulásban (Pikó, 2006). Az életminőség és társadalmi integráltság kétirányú kölcsönhatásban van. ,,az ok- okozati viszonyt azért nehéz meghatározni, mert az idősek integráltságának egyszerre következménye és oka is a társas és közösségi részvételük: egy jobban integrált személynek nagyobb lehetöségei vannak a társas részvétel különbözö formáinak gyakorlására, ugyanakkor a társas részvétel egyúttal a kapcsolat ápolásán keresztül a társas integrációt erősitő tevékenység is” (Kucsera 2012: 427). Az idősek integrációját makroközösségi szinten az határozza meg, hogy mennyire részesei, szereplöi a társadalom egészének. A mikroközösségi integráció, a társadalmi beágyazottság, tehát az egyén szubjektív életminőségét alakító legfontosabb tényező (Kucsera, 2012). Ezen megközelítésre alapozva feltételezhető, hogy az állatterápia közvetve segítheti az idősek társadalmi integrációját. A társállatokon keresztül növekedhet bizalmi szintjük, pozitívabb lehet önértékelésük, mely segítheti aktívabb társadalmi részvételüket, normakövető cselekvéseik változását, kapcsolathálóik virágzását. Az egyének társadalmi integráltsága annál magasabb, minél erősebb a valakihez vagy valakikhez tartozás érzése (Kucsera, 2012). A társállatok a jelenre irányítják az idősek figyelmét, és megmutatják nekik milyen értékesek ezek a pillanatok, amellett, hogy egyszerüen társaságot biztosítanak, az állatok egy bizonyos életritmus, életstílus fenntartására is rákényszerítik gazdáikat (Becker, 2002).

\section{Az egészség fogalma és társadalmi meghatározottsága}

Egészség szavunk jelentése: egész, hiánytalan, harmonikus, teljes. Az élet négy területét öleli fel, az egészséghez harmónia és összhang szükséges a természettel, önmagunkkal, embertársainkkal és a természetfelettivel (Váradi, 2007).

A WHO meghatározásai alapján, az egészség fogalma a következőképpen tágult az idők folyamán:

WHO, 1946: „az egészség nem csupán a betegség hiánya, hanem a teljes testi, lelki és szociális jóllét állapota”. 
WHO, 1984: „az egészség olyan fokon áll, amennyire az egyének és közösségek képesek önmaguk kiteljesitésére és szükségleteik kielégitésére, valamint képesek megbirkózni a környezet kihívásaival” (Pikó, 2006: 33-34).

WHO, 1986: „a mentális egészség, a jóllét azon állapota, amelyben az egyén képes a lehetöségeit kiteljesiteni, a normál stresszhelyzetekkel megküzdeni, produktívan és eredményesen dolgozni, valamint a közössége érdekében, hatékonyan közremüködni „(Kun, 2015: 50)

Pikó (2006) leírja, hogy egészségi állapotunkat több tényező befolyásolja, legfontosabbak láthatók a következő 1. ábrán. Az életmódbeli faktorok 43\%, a genetikai- biológiai faktorok $27 \%$, a környezeti tényezők $19 \%$ és az egészségügyi ellátás $11 \%$-os megoszlást mutat ebben a modellben.

1. Ábra: Az egészségi állapotot befolyásoló legfontosabb tényezők

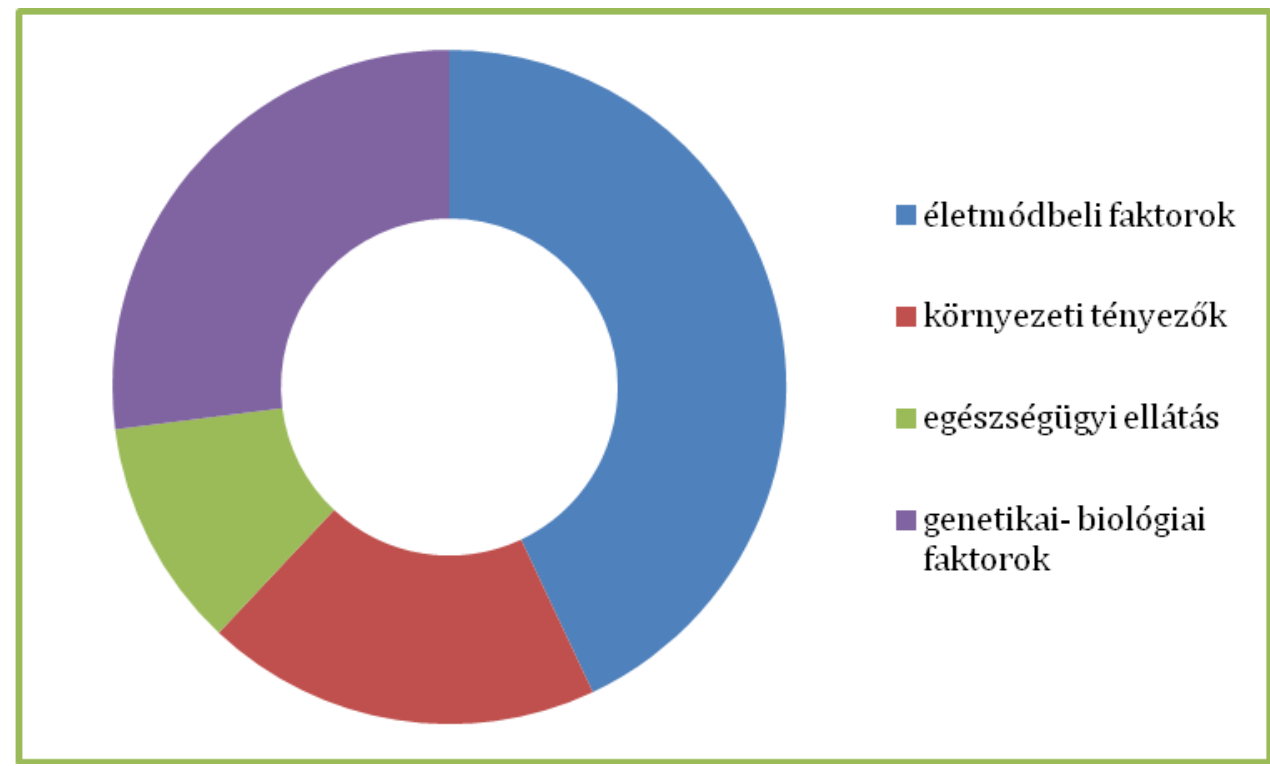

Forrás: Pikó, 2006:40

Az egészségi állapotot befolyásoló fent leírt tényezők figyelembevételével is hangsúlyozható, hogy az egészség egy komplex, több dimenzióból álló, holisztikus jellegü, egyén és környezete közötti, dinamikus egyensúlyi állapot. Az előbbi definíciók kiemelik a társadalom szerepét is az egészség értelmezésében, közvetve felhívják a figyelmet a szociális jóllét fogalmára. Ahhoz, hogy harmonikusan illeszkedjünk a társadalomba, egyensúlyra van szükség a saját önmegvalósításunk és a társadalmi szabályokhoz való alkalmazkodásunk között. A szociológia ezért kiegészítette a naturalisztikus egészségképet- mely csak a fiziológiás paramétereket, tekintette objektív mérőeszköznek- és a szociokulturális megközelítést helyezte elötérbe, mely 
a társadalmi normákat is beemelte az alapvető kritériumok közé. A társadalmi jelenségek függvényében kezdte értelmezni az egészség és betegség fogalmát. Az egészségkép társadalmi meghatározottságát segíti megérteni Parsons társadalmi egészségdefiníciója" Az egészség optimális képesség, hogy hatékonyan el tudjuk látni társadalmi szerepeinket, feladatainkat, amelyekre szocializálva vagyunk' (idézi: Pikó, 2006: 36).

Egészségünk állapotáról nagyon fontos képet ad laikus egészségképünk, vagyis az egészségünkröl alkotott szubjektív véleményünk. Ezt meghatározzák az egészség lelki és szociális dimenziói: boldogság, harmónia, kiegyensúlyozottság mellett, a hivatalos, aktuális egészségpolitika elvei, valamint a spirituális dimenziók és a kulturális, társadalmi helyzetünk. '’Az egészséggel, egészségkockázatokkal és betegségekkel kapcsolatos laikus vélekedések a hivatalos egészségdefiníciókat egészitik ki"' (Pikó, 2006: 38). Azzal a véleménnyel is találkozhatunk, ami egyenlőségjelet tesz a jóllét és az egészség közé (Atkinson, 2001), ezen érvelésben is fontos szerepet kap a szubjektív értékelés, a testi és lelki egészség szinte elválaszthatatlan fogalmak (Bakos, 2015).

Az ember egy komplex lény: biológiai, pszichikai és társadalmi tényezők ötvözete. Élettanibiokémiai folyamatai befolyásolják, a társadalmi normák és értékrendszerek hatnak gondolataira, érzéseire, hangulatára és az élethez való viszonyára. George Engel (1977) fogalmazta meg a biopszichoszociális modellt, mely tükrözi az emberi lét hármas feloszlását és integrált egységét. Kutatásom egyik kiindulási elméletének ezt a modellt tekintem, mely szerint az egészség biológiai; pszichológiai; és szociális rendszerek, komponensek összessége: - A Biológiai rendszer: az egészség és betegségfolyamatok anatómiai, strukturális és funkcionális jellegzetességei.

- A Pszichológiai rendszer: a pszichikai mechanizmusokat, pszichodinamikai folyamatokat tartalmaz.

- A Szociális rendszer: a társas funkcionalitást, a társadalmi magatartást és az egyén társas, csoportbeli viszonylatait jelenti (idézi Pikó, 2006: 17).

A modell továbbfejlesztett változata kiegészült a spirituális jelzővel, így a holisztikus emberképet fejezi ki, a biopszichoszociális- spirituális modell, ahol a spirituális rendszer: az egyén spirituálisa, hitvilága (Pikó, 2006).

Jelen írás elméleti alapjául szolgáló másik elmélet: Antonovsky koherenciaérzés- elmélete (1979, 1987) szerint, az életünk feletti kontroll érzése a koherenciaérzés, vagyis, hogy mennyire tartjuk világunkat kezelhetőnek, megérthetőnek és jelentőségteljesnek. Természetesen befolyásolják e látószöget egyéni és társadalmi jellemzők. Antonovsky hangsúlyozta, hogy ,, az az egyén, aki értelmét látja életének, aki megoldhatónak találja az élete 
során keletkezett problémákat, és képes megérteni a körülötte levö világ jelzéseit, könnyebben megbirkózik az egészséget veszélyeztető stresszekkel is” (idézi: Pikó, 2006: 43).

\section{Kutatás}

Kutatásom célja állat „baráttal” rendelkező, különböző szociokulturális környezetben élő idős emberek vizsgálata, tanulmányozása a szubjektív egészségi állapot, az egészség önértékelésének, az egészségkockázati magatartások gyakoriságának függvényében. Az állatoknak és az állattartásnak terápiás célból kiaknázható, szervezhető-szociális-mentális hatásait feltérképezni és a magánykerülő megküzdési stratégiákat azonosítani.

\section{Minta}

A vizsgálatomban résztvevő állattal rendelkező személyek az idős generációt képviselik. Kiválasztásuk egyik szempontja az volt, hogy 55 év fölöttiek legyenek, sóvidékiek, akik haszonállatot vagy háziállatot tartanak háztartásukban. A kutatás 2018-2020 közötti időszakban készült, 20 egyéni interjú és 150 kérdőív rögzítésével.

Kutatási területem a Sóvidék, a Kis- Küküllő felső szakasza mentén a Görgényi- havasok és a Hargita- hegység nyugati oldalán elterülő terület. $46^{\circ} 25^{\prime}$ és $46^{\circ} 40^{\prime}$ északi szélesség, valamint

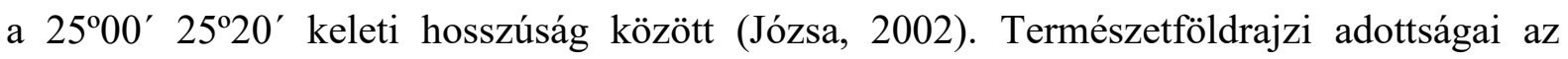
állattartást tették lehetővé a sóbányászat, fazekasság és fakitermelés mellett (Sófalvi, 2005). A térségben hagyományosan sok állatot tartanak, vidéken szinte minden családnak vannak háziállatai: szárnyasok, szarvasmarhák, lovak, sertések, juhok. A tradicionális mezőgazdasági termelés, az önellátó gazdálkodás a jellemző, sokszor a modern technikai, technológiai eszközök nélkül (Sallay, 2005). Legfontosabb települései: Alsósófalva, Atyha, Békástanya, Felsősófalva, Fenyőkút, Illyésmező, Kalonda, Korond, Pálpataka, Parajd, Sóvárad, Szováta.

\section{A kutatás módszerei}

A helyszíni kutatást megelőzően és azzal párhuzamosan könyvtári kutatómunkát végeztem, a szakirodalom feldolgozása, az elméleti keret meghatározásához. Az forrásokhoz való hozzáférést a Debreceni Egyetemi és Nemzeti Könyvtár, a Sapientia EMTE Csíkszeredai Karának könyvtára nyújtotta. A kutatás módszerei: az adatgyüjtés és az adatfeldolgozás módszereit jelentették. Az adatgyüjtés helyszíni terepmunkán valósult meg. A kutatásom célkitűzéseit szem előtt tartva, hogy minél objektívebben tudjam feltérképezni a kutatásban résztvevők egészségi állapotát és bio- pszicho- szociális jellemzőit az állatterápia függvényében, kevert módszertant alkalmaztam: kvantitatív és kvalitatív módszereket, interjút 
és saját készítésű kérdőíves adatfelvételt. A kérdőívbe beépített pszichoszociális kérdéseket a következő dimenziók alapján választottam: általános társadalmi jellemzők, társadalmi és társas kapcsolatok, egészség, képességek, értékek, valamint állattartással kapcsolatos kérdések, attitüdvizsgálat.

A standard kérdőívek közül a következőt használtam:

WHO JÓL-LÉT KÉRDÖIV (WBI-5), rövidített magyar változat, melynek belső megbízhatósága magas (Cronbach- alfa: 0,85). A kérdőív használható a különböző terápiás eljárások hatékonyságának vizsgálatára az életminőség szempontjából, az alanyok szubjektív megítélése alapján (Susánszky, 2006). Az Egészségügyi Világszervezet kutatócsoportja által kifejlesztett életminőségmérő módszer, hat fontos területet ölel fel:

- Fizikai állapot: a funkcionális kapacitás, bizonyos tünetek pl. fájdalom megléte, fizikai erőnlét;

- Pszichikai állapot: gondolkodás, érzések, hangulat, testkép, tanulási és memóriafunkciók;

- Függetlenség/ önállóság: képesség az önálló, mindennapos életvitelre, illetve munkavégzésre;

- Társas kapcsolati háló: társas kontaktusok mennyisége, a kapcsolatok minősége, társas támogatás;

- Környezettel való kapcsolat: lakókörnyezet, fizikai és társadalmi környezet, közlekedés lehetőségei, egészségügyi és szociális ellátás hozzáférhetősége;

- Lelki/spirituális jelenségek: hit, vallásosság, az élet értelméhez való viszonyulás (Pikó, 2006:37).

A verbális adatszerzési technikák közül kvalitatív módszerként, a mélyebb ok- okozati viszonyok feltárása érdekében, félig- strukturált szociológiai interjúkat vettem fel.

A mintavétel hólabdatechnikával történt, interjú alanyaimat randomszerüen választottam, illetve egyeseket a Pro Agricultura Hargitae Universitas Alapítvány folyóirata alapján kerestem meg.

\section{A kutatás eredményeinek bemutatása}

Miért reagálunk általában pozitívan az állattokra? Mi a társadalmi haszna? Ha végig gondoljuk, hogy rurális környezetben, ahol még fellelhetők az régi parasztgazdaságok és megfigyeljük ősapáink, ősanyáink vagy jelenleg hagyományos módon élő gazdálkodóink életét, kiknek élete még szorosan kötődik a természethez, belőle és általa élnek, tudásuk ősi, mely nemzedékről 
nemzedékre vándorol. Mindennapjaik nehézségei ellenére: korán kellés, nehéz fizikai munka, derüsek, vidámak, többnyire pozitívak.

Becker (2002) megfogalmazta, hogy ha az ember azt gondolja magáról, hogy senki sem szereti, és senkinek sincs szüksége rá, be is következik, ha viszont az ember egészséges, valaki másról gondoskodni tud, akkor szeretetre méltónak tartja magát, és az egész világról alkotott képe megváltozik, ez utóbbi megfigyelhető a megkérdezett állattartó gazdák esetében is. Az állatok a gazdálkodók számára, többszörös tőkét jelentenek: gazdaságit, kulturálist, társadalmit, szimbolikust, olyan rurális értéket, amely felgyorsult, globális társadalmunkban egy kihalófélben levő életformát, világot képvisel. A félig strukturált interjúk során összegyüjtött adatokat tanulmányozva, elemezve, a fogalmak közötti kapcsolatrendszereket figyelembe véve, a következőkben tárgyalt megállapításokra jutottunk.

\section{Pszicho- szociális jellemzők}

Az első kérdéscsoportban a válaszadók pszicho- szociális jellemzőit próbáltam feltérképezni. A kérdések az alanyok személyére vonatkoztak: kor, családi állapot, kikkel él egy háztartásban, iskolai végzettség, foglalkozás. Valamint kíváncsi voltam, milyen típusú megküzdési stratégiát alkalmaznak probléma megoldásra, ezért rákérdeztem vallásosságukra, társas kapcsolataikra. A válaszok alapján a megkérdezettek $31,33 \%$ férfi és 68,67 \% női állattartó. Életkoruk alapján legtöbben (72-en) hetvenes éveikben járnak, átlag életkoruk 68,71 év. Elindulási időpontként (mióta foglalkoznak állattartással) legtöbben a nyugdíjba vonulást említették, az egyik tipikus érv a magyarázatra, hogy a mai kor emberének, már nem kielégítő az a minimális összeg, amit a nyugdíjból kap, ezért igyekszik más jövedelemforrást is találni.

Iskolai végzettségüket tekintve, legtöbben érettségizettek (60 személy), a többiek közel azonos arányban egyetemi vagy főiskolai végzettségűek, illetve általános iskolát vagy nyolc osztálynál kevesebb osztályt végeztek (2. ábra). 


\section{Iskolai végzettség}

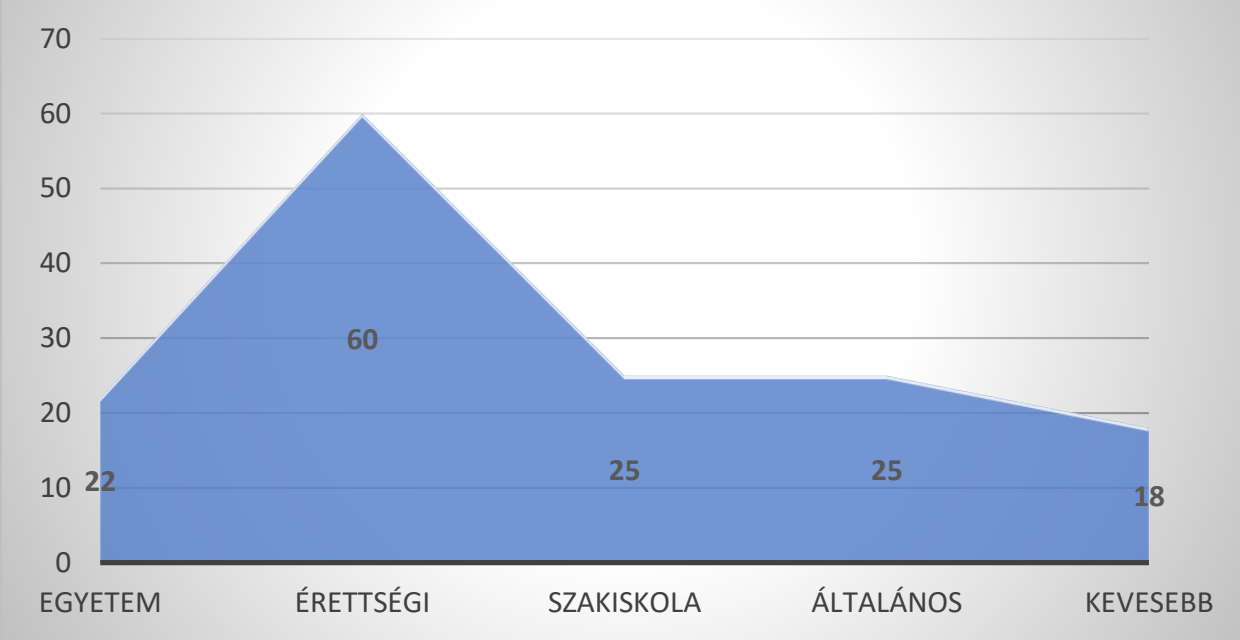

2. ábra: Kutatási alanyaim iskolai végzettsége- Forrás: saját szerkesztés

A megkérdetettek 38\% a házastársával él egy háztartásban, többiek különböző százalékban gyerekkel, albérlővel és 30\% egyedül csak az állatával (3. ábra).

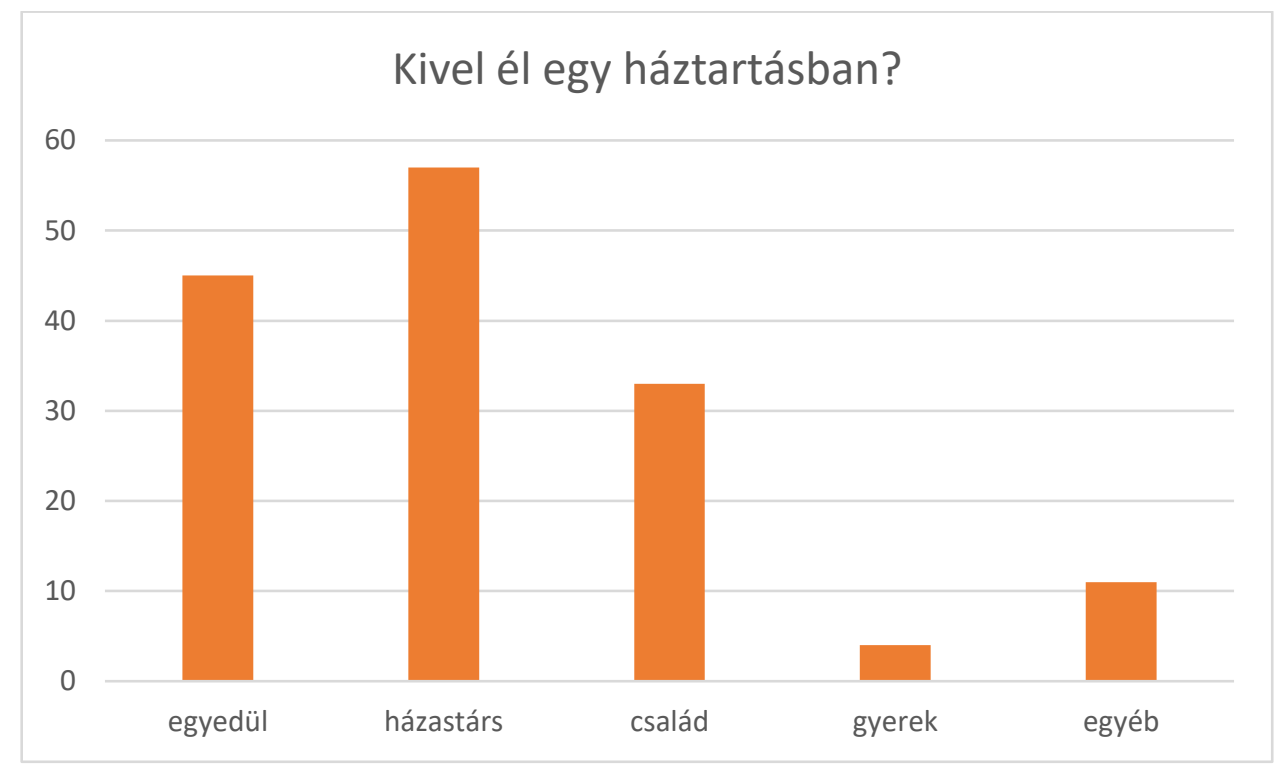

3. ábra- Kivel él egy háztartásban? - kérdés válaszai. Forrás: saját szerkesztés

Legtöbben a család valamely tagjával, házastárssal vagy gyerekkel beszélik meg problémáikat, az egyedülállóknál a beszélgető partner a barát, szomszéd, a pap vagy a szociális munkás (4. ábra). 


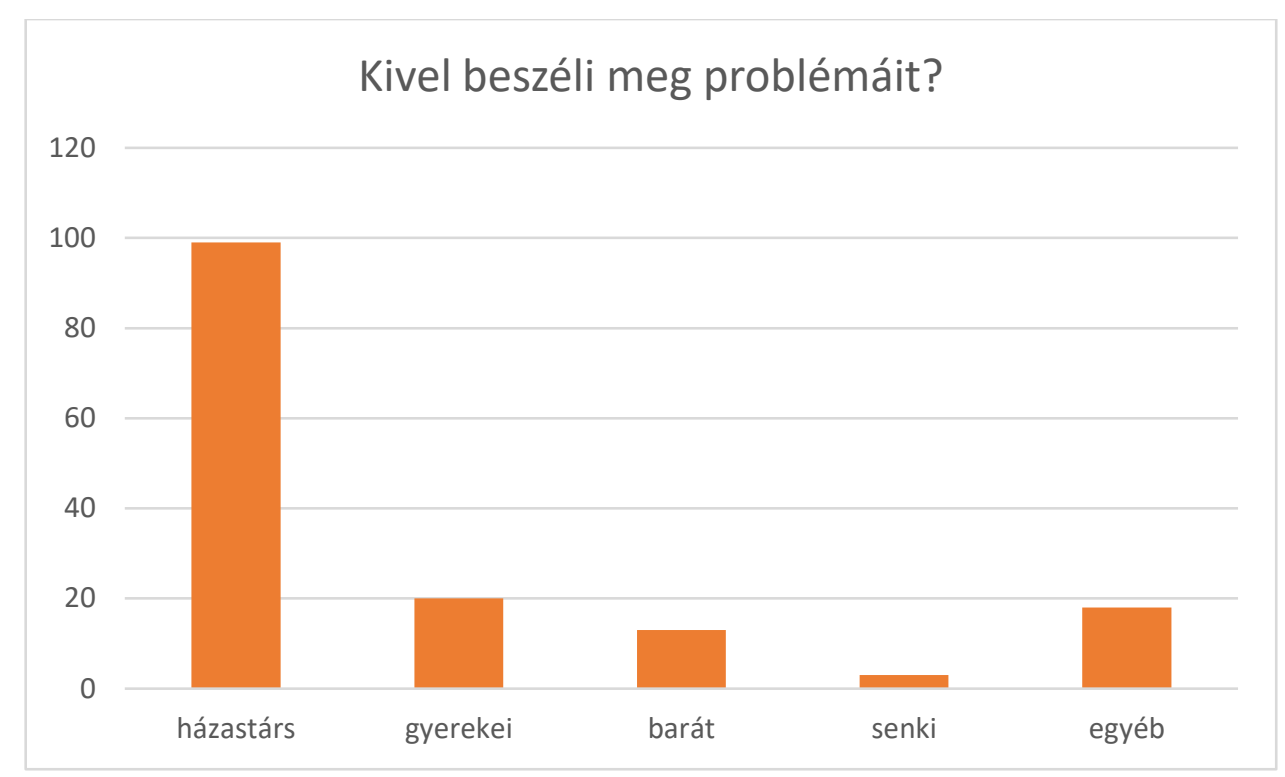

4. ábra: Kivel beszéli meg problémáit? - kérdés válaszai. Forrás: saját szerkesztés

Arra a kérdésre, hogy általában „Szeretnek-e társágba járni?” a válaszadók többsége igennel válaszolt (5 ábra).

A megkérdezettek 99\% vallásosnak tartja magát.

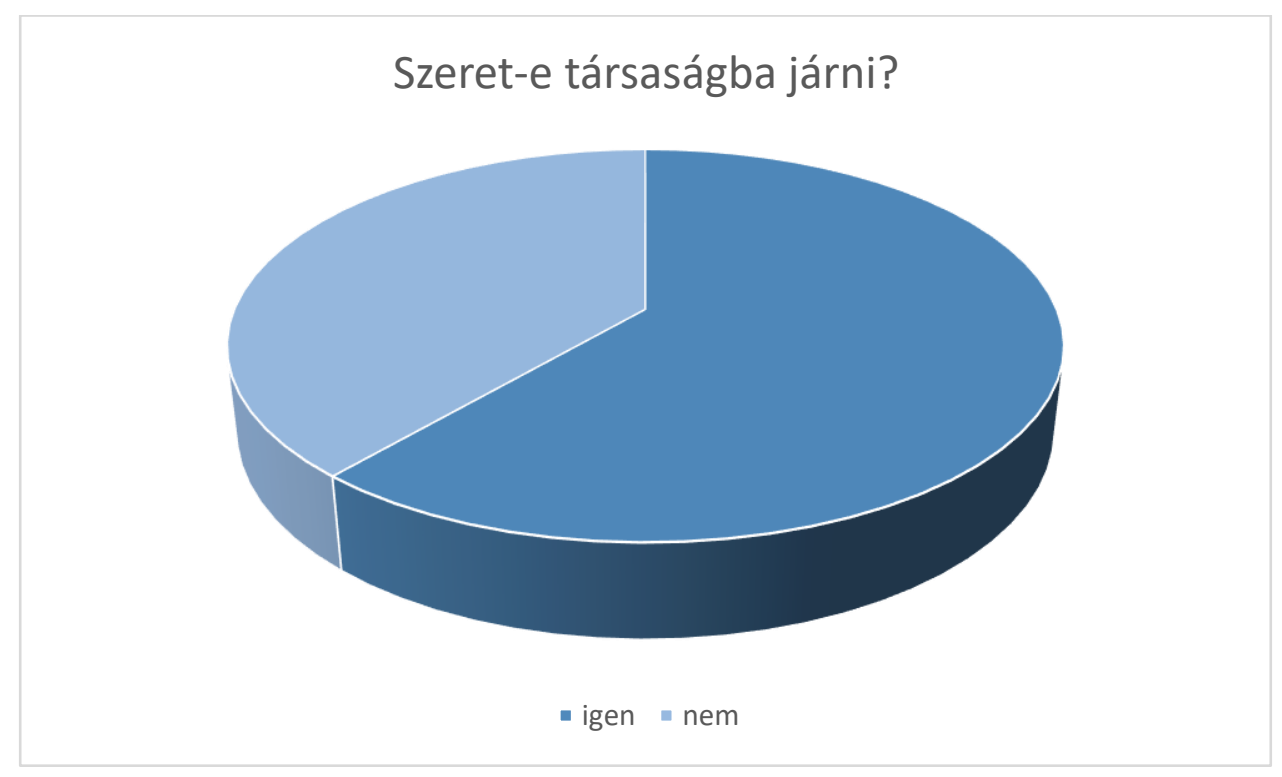

5. ábra - Szeret-e társaságba járni? - kérdés válaszai. Forrás: saját szerkesztés

Az adatok alapján megállapítható, hogy leginkább a problémaközpontú megküzdés jellemzi őket, a probléma megváltoztatására összpontosítanak, a leggyakrabban használt megküzdési stratégiák dimenziói: az aktív megküzdés, a pozitív újraértékelés, az elfogadás és a tervezés. Az állatok, életükben szociabilitást segítő faktorként jelenek meg, jelenlétükben könnyebben 
megy a kommunikáció, kommunikációs csatornák szélesednek, változatosabbak. Az egyik válaszadó, M. néni beszámolójából egyértelmủen kiderül, hogy az ő beszélgetési palettája állatainak köszönhetően szélesedett. Egy másik válaszadó, L. néni esetében is hasonló a helyzet, aki igy fogalmazott azzal kapcsolatban, hogy mi történik míg a negyven tejhordója elviszi a napi adagot:

„,Még igen sokat beszélek. Mindenkivel beszélek. A férjem is egy kicsit olyan hallgatag a fiam is, akkor mind mondja reggel is mikor jönnek a nénik is a tejért. Miért mind beszélek annyit, hát mindenki elmondja hogyan aludt mit csinált, akkor engemet érdekel, ki kisérem akkor mondják miért kisérem ki, hát azért, mert addig még beszélgetünk”' (2. interjú alany, L, néni).

\section{Állattartás}

A román országos átlaghoz viszonyítva a sóvidéki állattartás elenyészőbb (net3.). A községi polgármesteri hivatalok nyilvántartásai alapján községekénti állattok számát az 1. táblázat tartalmazza.

1. Táblázat: Sóvidéki háziállatok száma községenként.

\begin{tabular}{|c|c|c|c|c|c|c|c|c|}
\hline Község & $\begin{array}{c}\text { Marha } \\
\text { félék }\end{array}$ & $\begin{array}{c}\text { Sertés } \\
\text { félék }\end{array}$ & Juh & Kecske & Szárnyasok & Ló & Nyúl & Méhek \\
\hline Korond & 2450 & 720 & 2500 & 360 & 3200 & 209 & 260 & 1178 \\
\hline Parajd & 1246 & 449 & 6157 & 508 & 2910 & 66 & 60 & 1704 \\
\hline Szováta & 515 & 507 & 3885 & 515 & 4359 & 140 & 720 & 2115 \\
\hline
\end{tabular}

Forrás: a községek Polgármesteri Hivatalának adatai alapján, saját szerkesztés

Az Állategészségügyi Körök statisztikai adatai alapján ez az állatállomány Korondon 783, Parajdon: 552 és Szovátán 45 gazdánál oszlik meg. Az állattartó gazdák életkorát tekintve 70\% ötven év feletti. Nyilvántartják a kutya és macskatartókat is, ami Korond községben: 985, Parajd: 1089, Szováta:1655 gazdát jelent.

A kutatásban résztvevő állattartók, arra a kérdésre, hogy „Hány éve tart állatot”, átlag 13, 64 évet jelöltek meg (6 ábra). 


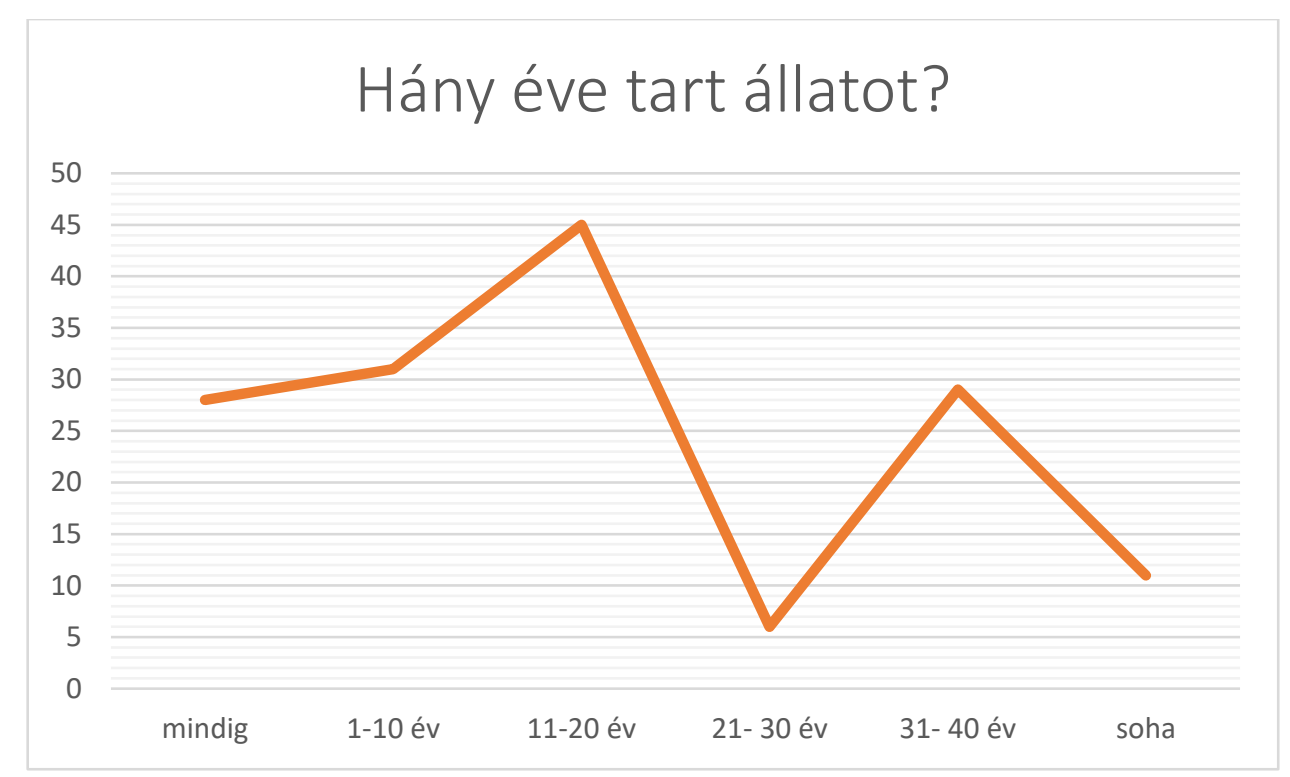

6. ábra- hány éve tart állatot? - kérdés válaszai. Forrás: saját szerkesztés.

A megkérdezettek átlagosan napi 4, 901 órát foglalkoznak állataikkal.

A vizsgálati alanyok perspektíváit és nézőpontjait, mindennapjaikat figyelembe véve megállapítható, hogy falusi környezetben a legértékesebb tőke a föld és annak élővilága. Elfogadják és tisztelik a természet erejét, melyet szolgálnak, és nem birtokolnak. A parasztság egy önellátó életforma, megtermeli magának az ételt, italt, ruhát, erkölcsös életet él, a lopás szégyen, az adott szó szent. Az állatokról alkotott gondolkodásukról megállapítható, hogy véleményüket kettősség jellemzi. Elöször is az állatokra eszközként tekintenek, célszerüségüket hangsúlyozzák: haszonállat, élelemforrás, jövedelem kiegészítő:

- '’Szoktunk eladni, akkor meg van nekünk az élelmünk, tojás, tej, hús nem kell, hogy megvásároljuk ezeket. Szeressük, na' (1. interjú alany)

- ' 'a férjem is szereti az állatokat. Még egy kis jövedelem is és foglalkozunk'” (3. interjú alany)

- „mert pénzhez hozzá segítettek, megélhetési forrás, ez olyan, mint bárkinek a munkahely” (5. interjú alany)

- „,érdemes tartani, mert hasznos állat, pénzt hoz a házhoz elég szépen” (8 interjú alany)

- „megéri ezt csinálni, mert ezért a faluból nem kell kimenni. Itthon van az ember, s ezt akárhogy csinálja” (12. interjú alany)

Ugyanakkor antropomorf jellemzőiket is hangsúlyozzák: szociális, érző, értő lényként tekintenek rájuk. 
- ' 'Szoktam, sokszor beszélek az állatokkal. Nincs olyan reggel, hogy ne menjek be mondjak nekik jó reggelt, hogy aludtatok. Na...nevet. Mindig szólok hozzájuk. (2. interjú alany)

- Reagálnak, az állat is érzi, ha szereted, mert ha durva vagy akkor nem, látszik, hogy húzódik el töled" (3. interjú alany)

- ' 'Ez amelyik van most olyan jámbor, jön utánunk, éppen nem beszél. (4. interjú alany)

- Beszélgetek velük, persze mondom, neki Cifrának hívják a tehént, hogy adjál sok tejet, mert ma reggel sokan viszik. Mintha tudná, hogy mit mondok, úgy nézz, úgy nyalja, kidugja a nyelvét, csókolja a kezem nekem meg a férjemnek is" '(1. interjú alany)

Az állatok, a föld tőke, áldás a család részére, a gondviselés ajándékai, a környezetet nem védik, hanem élnek rajta, vele. Fontos összekötő kapocs interjú alanyaimnál, hogy mély érzéseket táplálnak, szeretik állataikat:

- '’Szeretem, nagyon szeretem. Egész nap el lehetne velük beszélgetni. Megyünk az istállóba, már úgy tudja a tehén, nyal, csókol" (1. interjú alany)

- 'Állataimat. Igen, igen nagyon szerettem. Mindegyiket szeretem, így van. Nincsen különbség, hogy melyiket jobban" (2. interjú alany)

- ' 'szeressük na. Megéri, hogy foglalkozzak vele, mert érzem, hogy szeret' (3. interjú alany)

- ''Buksi a fö, vele, ha süt a nap, ha havaz hozzá megyek, mert tudom, hogy vár engem és akkor megyek. ez egy természetes dolog'” (6. interjú alany)

Ismereteik, tudásuk, nemzedékről nemzedékre vándorol, magukba szívjak, szülőktől, szomszédoktól, autodidakta módon, saját bőrükön tapasztalják, bővítik, fejlesztik (tapasztalati tanulás). A pásztor nem könyvböl tanult, hagyományos ökológiai tudással rendelkezik, mindennapi élete köti az erdöhöz, gyepekhez, kooperálnak a természettel, miközben használják, búzát, termelnek, marhát nevelnek. A marginalizálódott szereplőktől eltekintve a jó juhász tudja, hogy fenntarthatóan kell használnia a legelőt, a jószág száján át látni azt, minden döntést az elődök tapasztalata alapján és az utódok figyelembevételével igyekeznek meghozni, hosszú időtávban, közösségben és túlélésben gondolkodnak (Babos, 2020):

- 'Állattartó ismereteket, hát igazából már az iskolában is tanultunk, a szomszédoktól megkérdeztük, amit nem tudtunk. a szüleinktöl még éltek, amikor bele mentünk. Így öröklödik egyik ágról a másikra'” (3. interjú alany) 
- 'láttam édesanyám mit csinál, mit csinál a tehénnel. Többet a férjem, mert ö árván nöt fel az édesapja meghalt, amikor 14 éves volt és maradót egy csomó tehén. ö tanitott meg kapálni, ö tanított meg állatokat gondozni" ' (1. interjú alany)

- ' 'úgy beléjöttünk. Tartottunk, akkor még többet, s még többet'” (2. interjú alany).

\section{Egészség}

A kutatás egyik főcélja az volt, hogy feltárjam van-e pozitív hatása az állatnak (haszon és házi) az állattartó egészségére, ezért az utolsó kérdéskör kérdéseit ennek megfelelően állítottam össze, és az alanyaim egészségi állapotának feltérképezésére használtam (7. ábra).

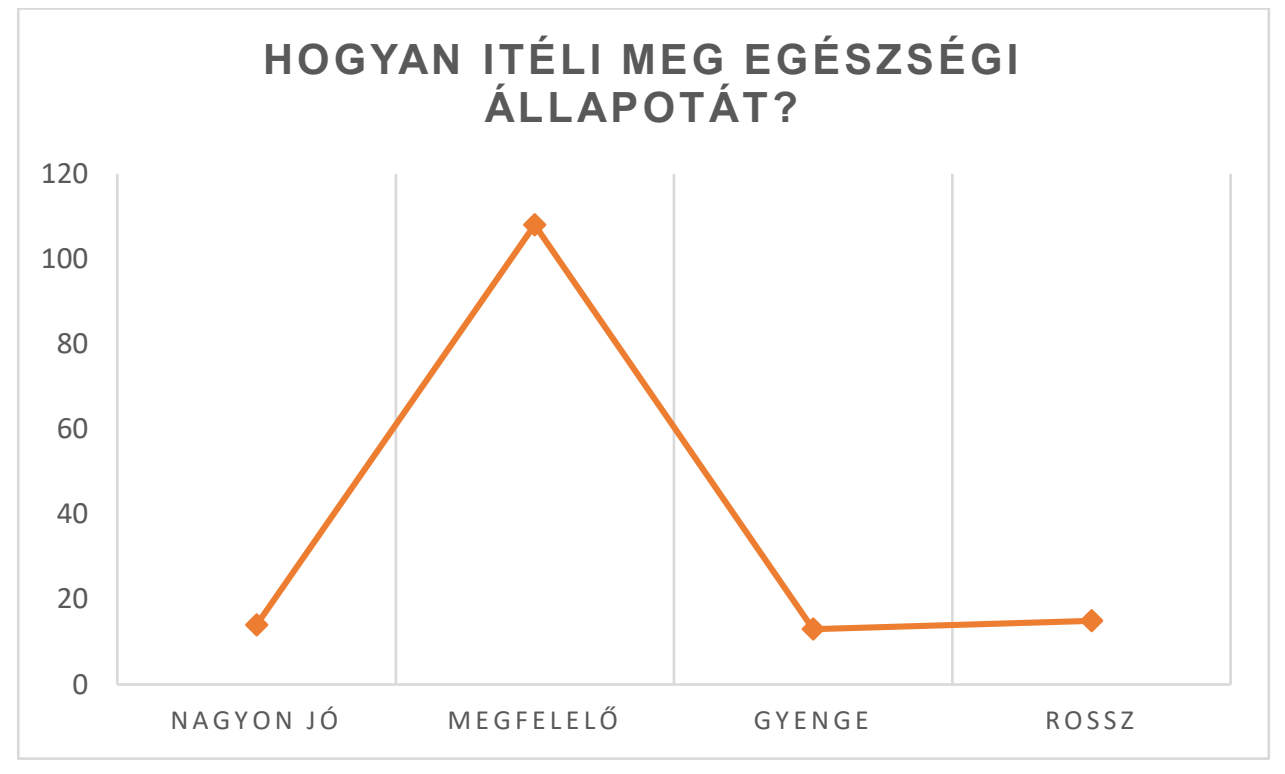

7. ábra: Szubjektív egészségkép. Forrás: saját szerkesztés

Saját szubjektív értékelésük szerint teljes egészében egészségesnek, egyik megkérdezett sem vallja magát. Felsorolják betegségeiket, gyógyszereiket, de valamilyen formában azért mind hálát adnak a jó Istennek, hogy jó a helyzetük, pozitívan gondolkodnak:

- 'Hát mit mondjak, a jó Istennek hálát adok eddig'” (2. interjú alany)

- ', még mind szaladgálok, még nem vagyok görbe, nem járok bottal. Örvendek, hogy a jó Isten ilyen egészséget is adott"' (3. interjú alany)

- „, segített abban, hogy egészséges legyek. Az állat mellett nincs idö azon gondolkodni, hogy beteg vagyok vagy sem" (17. interjú alany)

- „az egészségünk Hála Istennek megfelelö, kisebb nagyobb problémák néha akadnak, de általában minden rendben" (19. interjú alany) 
Orvost gond esetén és felülvizsgálatkor keresnek fel (8. ábra).

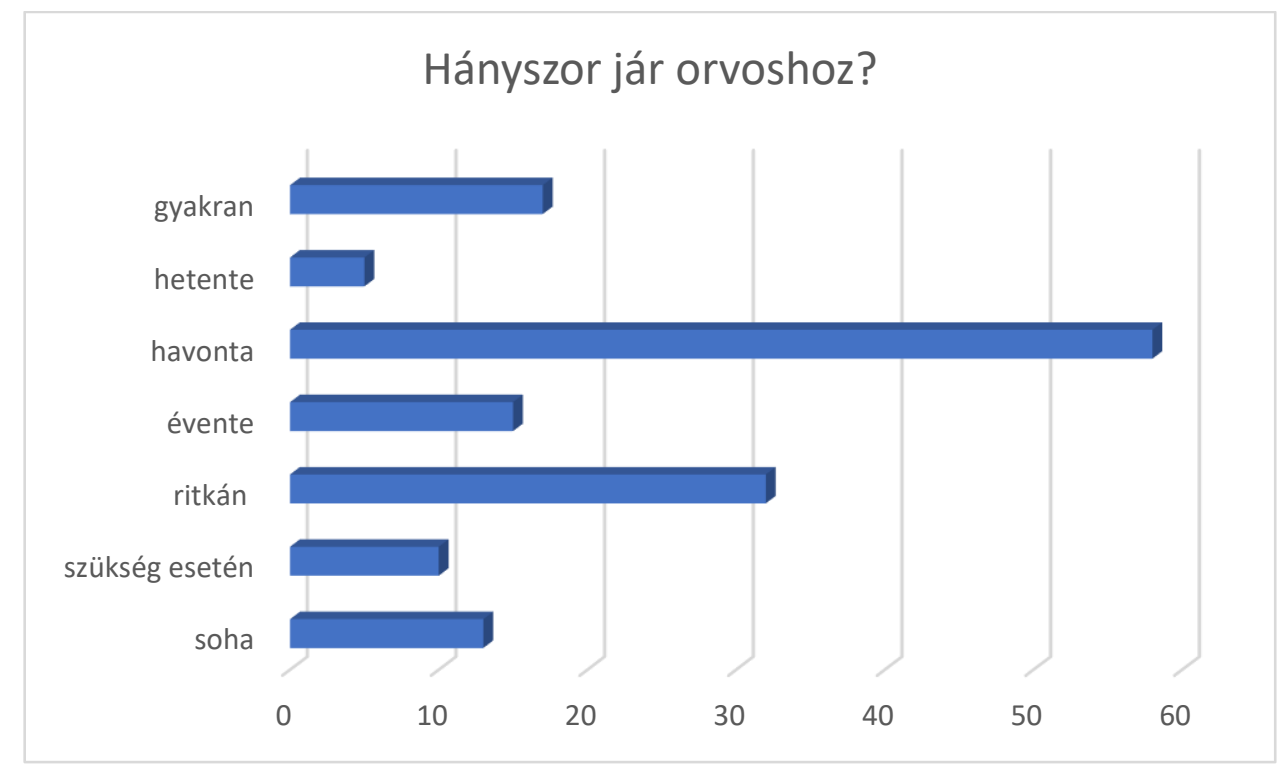

8. ábra: Hányszor jár orvoshoz kérdés válaszai. Forrás: saját szerkesztés

Az Eurostat, 2017-es adatbázisa szerint, az orvoslátogatás gyakoriságát tekintve, Románia az európai átlag alatt szerepelt (net1.). A lakosság 41\% nem jár orvoshoz, további 13\% évente egyszer, kétszer. 5\% a lakosságnak az, akik rendszeresen igénybe veszik az egészségügyi szolgáltatásokat (9. ábra).

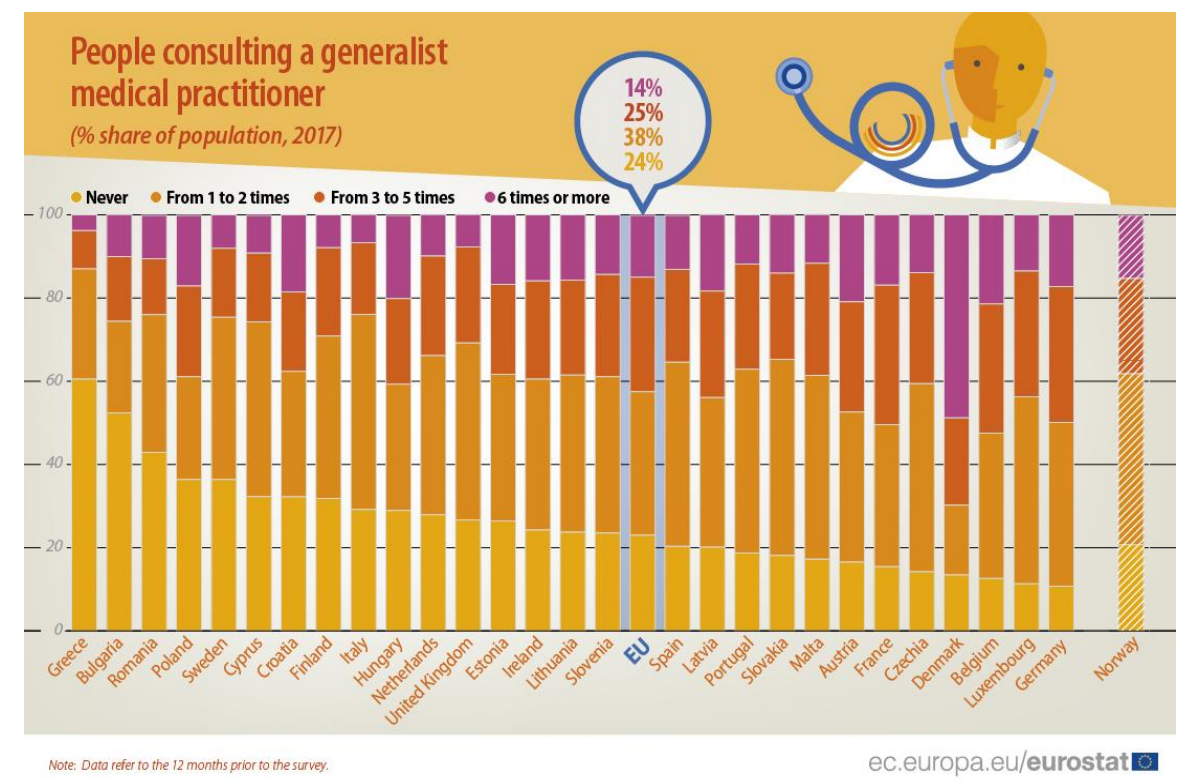

9. ábra. Az Európai Unió országaiban az orvoslátogatás gyakorisága. Forrás: net1.

(Eurostat, 2017.) 
Az OECD országokban a daganatos-, keringési-, légző- és emésztőrendszeri betegségek okozzák az elhalálozások 90\%-át (net2.). A sóvidéki családorvosok 2019 évi jelentése, a Hargita Megyei Egészségbiztosítási Pénztár felé, a következő betegségekkel kezelt pácienseket tartalmazza, gyakorisági sorrendben: magas koleszterinszint, magas vérnyomás, szívbetegség, cukorbetegség, asztma, ízületi gyulladás, reuma, allergiás betegség, idült hörghurut, depresszió, tüdőtágulás, csontritkulás, szívroham, szívinfarktus, agyvérzés, rosszindulatú daganat.

A kutatásban résztvevők válaszaik alapján, megfigyelhető az állatoknak pozitív mentálhigiénés hatásai gazdáikra nézve, hozzájárulva ezzel a pszichoszomatikus betegségek kialakulásának prevenciójához:

- 'Még az állatok sokat segítenek a bánatomon, a lelki állapotomnak is" (3. interjú alany)

- 'Mindig megnézem, mikor látom, olyan boldog vagyok, úgy várják, az eledelt, szaladgálnak, örvendek én is. Jobbá teszi az életünket, a mozgásunkat’' (1. interjú alany)

- 'Jól esik, hogy az állatokat elrendezed és akkor szépek'” (2. interjú alany)

- 'el kell foglalja valamivel magát, mert szellemileg beteg és a ló maga gyógyítja, úgy beszélget a lóval, mintha egy élölény lenne neki, társa lenne. Ez élteti a fiamat'” (3. interjú alany).

A WHO öt tételes, jóllét kérdőívével az egyének általános közérzetét vizsgáltuk, a kitöltést megelőző kéthetes időszakra vonatkozóan.

A válaszadók élettel való elégedettségéről megállapítható, hogy az elmúlt két hét során az állattal rendelkező gazdák 47.9\%-a teljesen vidámnak és jókedvünek érezte magát.

„Az elmúlt két hét során érezte-e magát nyugodtnak és ellazultnak?” kérdésre, az állattartó gazdák 47.9\% jellemzőnek, 25.2\% teljesen jellemzőnek, 23.9\% alig jellemzőnek, míg 3\% egyáltalán nem találta önmagára jellemzőnek az ellazult állapotot.

Aktívnak és élénknek az állattartó gazdák 48.3\% jellemezte az elmúlt két hét kedélyállapotát. Ébredéskor frissnek és élénknek, a megkérdezettek 47.4\% érezte magát, 2.6\% egyáltalán nem találta jellemzőnek magára nézve.

„Az elmúlt két hét során, a napjai tele voltak-e az ön számára érdekes dolgokkal?” kérdésre a minta 47\% vallotta, hogy igen jellemző rá, 4.3\% alig jellemző választ adott.

A kérdőív eredményei alapján látható, hogy a kérdőív leírásában korábbiakban bemutatott hat fontos részterületen az állattal rendelkező gazdák mutatói nagyon jónak mondhatók. 
Az interjúkban a válaszadók összefoglalóan igy fogalmazzák ezt meg:

- „mert ugye, mint mérnöknö is dolgoztam, meg annyi papírt túrtam, hogy rettenetes. Úgy jöttem haza, hogy olyan haszontalannak éreztem magam, olyan nehéz volt, annyit küzdöttem ezzel. S most egy ilyen paraszti munkával annyira hasznosnak érzem magam (7. interjú alany)

- „mert az Isten tenyerén mindenki jól van. Nem kell sem orvos, sem pszichológus, csak a munka és a müvészet" (3. interjú alany).

\section{Konklúzió}

Kutatásommal és az adatok elemzésével hozzájárultam Cicero örökérvényü szavainak megerősítéséhez: ,semmi sem méltóbb az emberhez és semmi, sem tesz szabadabbá, mint a gazdálkodás”. A kutatásban szereplő idősek véleményét feltárva látható, hogy az állattartás nem csupán egy életforma, hanem naponta ismétlődő társadalmi rítus, szimbolikus értékekkel, társas interakciókkal (Giddens, 2008). Az állattartó idősek életvitelüknek köszönhetően sokat tesznek egészségük megőrzéséért, mivel a saját gazdaságuknak köszönhetően egészségesebben, természet közelibben táplálkoznak, gyakrabban esznek teljes kiőrlésü gabonát, bio zöldségeket és gyümölcsöket, saját tenyészetből hústerméket, tejterméket. Fizikai aktivitásuk, testmozgásuk, a mindennapi munka miatt intenzívebb, ami egészségi állapotukra pozitívan hat. Leleményeségük, természetszeretetük, hagyományos tudásuk, civilizációs ártalmaktól mentes közegük preventíven megelőzi, számos testi- lelki betegségük kialakulását, patikává válik a körülöttük levő világ.

Kutatási eredményeim azt is alátámasztják, hogy időseink, akik értelmét látják életüknek, megoldhatónak találják problémáikat vélhetően sokkal könnyebben megbirkóztak az egészséget veszélyeztető stresszekkel.

Az állatokról való gondoskodást Székelyföldön, a Sóvidék falvaiban vizsgált idősek körében kettőség jellemzi. Állataik haszonállat funkciót töltenek be, kereskedelmi céllal tartva, ugyanakkor a paraszti kultúra mindennapjaihoz hozzá tartozik, hogy figyelnek, törődnek, kötődnek állataikhoz, empátiát és további pozitív érzelmeket figyelhetünk meg kapcsolatukban. 


\section{Összegzés}

Az állattok az emberek számára egészségmegőrző hatással rendelkeznek, a társállattal való fizikai kontaktusnak, interakcióknak közvetlen pszichológiai, kognitív hatásuk van, melyek mérhető módon tükröződnek egyes fiziológiai paraméterek pozitív változásában (Topál, 2011). A társállat mentális egészségvédő faktor. Jelen kutatás eredményei is szolgáltatnak ezen kijelentést megerősítő adatokat, Topál (2011) kutatási eredményeivel összhangban. Az emberállat interakciónak indirekt hatása is van, a szociális facilitáción keresztül, azáltal, hogy megkönnyíti az emberek közötti szociális integrációt (Topál, 2011).

Az állatterápia aktív megküzdési stratégiák használatára ösztönöz. A problémaközpontú megküzdés esetén a személyek a probléma megváltoztatására összpontosítanak. Eredményeim azt támasztják alá, hogy az állatbaráttal rendelkezőknél a leggyakrabban használt megküzdési stratégiák dimenziói: az aktív megküzdés, a pozitív újraértékelés, az elfogadás és a tervezés, mig az állatbaráttal nem rendelkező személyeknél a vallás és az eszköz jellegű szociális támasz keresése a domináns.

Az állat szociobilitásra ösztönző tényezö. Az állat jelenlétében, könnyebben megy a kommunikáció, kommunikációs csatornák szélesednek, változatosabbak. A haszon és háziállatokon keresztül növekszik a gazdák bizalmi szintje, pozitívabb lesz az önértékelésük, mely segíti aktívabb társadalmi részvételüket, normakövető cselekvéseik változását, kapcsolathálóik gazdagodását.

Mindezen komponensek alapján az Engelsi és Antonosky modellben foglaltakat megerősítő eredményekről számoltam be.

A kutatás egy további irányvonala lehet a kontroll csoport, vagyis azon válaszadók kutatásba bevonása, akik a jelen kutatásban megkérdezett személyektől csak annyiban különböznek, hogy nem tartanak állatot. Az ő véleményük feltárásával kaphatunk még árnyaltabb képet az állattartás idős személyekre gyakorolt hatásairól.

\section{Ábra- és táblázatjegyzék}

1. ábra: Az egészségi állapotot befolyásoló legfontosabb tényezők

2. ábra: Kutatási alanyaim iskolai végzettsége

3. ábra- Kivel él egy háztartásban? - kérdés válaszai

4. ábra: Kivel beszéli meg problémáit? - kérdés válaszai

5. ábra: Szeret-e társaságba járni? - kérdés válaszai

6. ábra: Hány éve tart állatot? - kérdés válaszai

7. ábra: Szubjektív egészségkép 

8. ábra: Hányszor jár orvoshoz kérdés válaszai
9. ábra. Az Európai Unió országaiban az orvoslátogatás gyakorisága
1. táblázat: Sóvidéki háziállatok száma községenként

\section{Irodalomjegyzék}

Atkinson, R.L. \& Atkinson R.C. (2001). Pszichológia. Budapest, Osiris Könyvkiadó

Babos, K. (2020). Mi a közös egy székelyben és egy ausztrál bennszülöttben? Etnoökológust kérdeztünk. Transindex.ro: 2020.02.11. elérhetö: https://eletmod.transindex.ro/?cikk=28247

Bakos, K. (2015). A pedagógusi szerep dilemmái és összefüggései az életminőséggel, In: Metszetek, 4(1) pp. 3-14.

Becker, M. (2002). Az állatok gyógyító ereje. Budapest, Gold Book Könyvkiadó

Giddens Anthony (2008): Szociológia. Osiris kiadó, Budapest.

Hewstone, M., \& Stroebe, W. (2007). Szociálpszichológia. Budapest, Akadémiai kiadó

Illés, A. (2006). AI módszer a kutyás terápiában. elérhető: http://mek.oszk.hu/03800/03851/index.phtml

Józsa, A. (2002). A Sóvidék és fürdői. Korond

Kucsera, Cs. (2012). Egyedül élő budapesti idősek társas és közösségi részvételét gátló szubjektív okok. Társadalmi integráció könyv tanulmánya. MTA Társadalomtudományi Kutatóközpont. pp. 427- 440.

Kun, Á. (2015). A jóllétet meghatározó tényezők vizsgálata egészségügyi szakdolgozók körében. Alkalmazott Pszichológia, 15(2) pp. 49- 71

Pikó, B. (2006): Orvosi szociológia. Budapest, Medicina Könyvkiadó

Sallay, Á. (2005). Tájvédelem és fejlesztés a Firtos kistérségben. Táj építészeti és Kertmüvészeti Folyóirat. pp.31-36

Sátori, Á. (2007). Az állatokhoz való viszony a társas-társadalmi kapcsolatok rendszerében. Budapest, Elte

Sófalvi, A. (2005). Sóvidék a középkorban, Székelyudvarhely, Haáz Rezső Alapítvány

Susánszky, É. (2006). A WHO Jól-lét kérdőív rövidített magyar változatának validálása a Hungarostudy 2002 országos lakossági egészségfelmérés-alapján. elérhető: 
http://magtud.semmelweis.hu/files/kerdoivek/WHO_jollet_kerdoiv_\%28WBI-

5\%29_validalo_tanulmanya.pdf

Váradi, T. (2007). Út az egészség felé. Mesterkurzus. A megismerés útjai. Tanulmánykötet. Saxum kiadó.

\section{Internetes források}

net1. https://ec.europa.eu/eurostat/data/database

net2. https://stats.oecd.org/

net3. https://insse.ro/cms/

A szerző:

\section{Virginás Zolna}

Debreceni Egyetem, Szociológia és Társadalompolitikai Doktori Iskola, IV. éves phd hallgató, Cím: Korond, Hargita megye, Románia, mobil: 0040752527945 , zolna4@yahoo.com 